\title{
管内気流による比重分級の基礎研究（I ）
}

\author{
——気流中の代表粒子の運動とその数学的表現—
}

\author{
坂 本 定 男* \\ Fundamental Study on the Gravity Classification of Particles in Air Duct (I) \\ - The Motion of a Representative Particle in Air Current and \\ its Mathematical Expression
}

Sadao SAKAMOTO

\begin{abstract}
The method using air flow is investigated to dress particles in similar density from some sorts of same size particles. Each gravity centers of distribution of similar weight particle have to keep some distance on the gravitational section to get the effective result by this method. To acquire the distance between gravity centers, in the first place, the gravity centers must be defined. Then the purpose of this article is to state on the calculation method of gravity center.

A co-ordinate of gravity center can get from the equation of motion concerning a representative particle, because it can be considered that a curve put the points of gravity centers in a row is a path line of the representative particle.

Results gained by this way are examined by experiments used glass beads.
\end{abstract}

1. はじめに

粒子の比重分級を気流で行なうには，粒子の運動が比 重の影響をうりる性質を利用しなければならない。ニュ ートンの運動の法則によれば，粒子の比重は確かに粒子 の運動を規定する一因子ではある。しかしながら，粒子 の運動に影響を与えるものは比重のみではない。径の大 きさや形状むまた大きな影響を与える。自然界に存在し たり，容易な製法により得られる粒子群では，そのなか の個々の粒子の大きさは平均径のまわりにある広がりを あって分布し，形状は不規則なあのが多い。それらを輸 送する気流の性質は勿論平均速度により規定される。そ のようなととを考え合せれば，いかに平均径を選たくし， それに加えて比重の一様な粒子を揃えてあ，気流中の一 個一個の粒子の運動をニュートンの法則で説明するてと は容易ではなくなる。個々の粒子の運動は，壁面や粒子 相互の束縛がなければ，多分平均的な運動のまわりにあ る広がりをむった形態として表わすのが好都合のように 考えられよう。むしそうだとすれば異なった比重の粒子

* 熊本大学教育学部 昭和50年 9 月 30 日受理
の集りを，気流を用いて同比重の粒子の集り毎に分ける には，それぞれの比重でとの粒子群が重複して位置を占 めないととが必要になる。すなわち，それら粒子群の分 布重心間の距離が比重の差異に応じて離れ，その重心間 の距離に対して，それぞれの粒子群の分布の広がりの小 さいととが望ましくなる。重心間の距離を求めるには, まず分布重心を求める必要がある。乙てでは比重分級に 関する以上の 2 因子のうち，まず分布重心について考察 するあのとする。

管内気流中での比重分離を考えているので，実用的な 利用度扣よび実験上の都合から“粒子の流量分布重心” を計算により求める方法についてのべる。そして，てれ まで最む研究し尽されたとされている球粒子を用いて実 験を行ない，その結果と理論計算の結果とについて報告 する。

\section{2. 泣子の流回分偙重心の計算}

輸送流体により流動する粒子群の分布については，乙 れまでに多数の研究結果 ${ }^{1 \sim 11)}$ が報告されているが，分 布の重心に関する研究例は少ない。それは，これまでの 
研究が粒子分布の定常域の屯のであり，管底または河川 底や海底を基準に分布を表わすととが可能であったから である。しかるに，ここでは比重分級に役立てるために 分布が変化している粒子供給孔近くの領域を取り扱うの で，管底を基準に分布を表わすよりむしろ重心まわりに 表わすほうが好都合のように判断される。それでまず流 量分布の重心を理論的に求めようとするものである。

基礎的研究として，粒子は球または等価な球として取 り扱いが可能なあのと仮定し，その粒子を輸送管上壁の 点源加管内気流中に供給し，それらが相互干涉なしに 輸送される際の流量分布重心について考えることにする。 ただし，一般の粒子では形状が不規則なため，抵抗係数 は平均值 ${ }^{12,13)}$ で表わさざるを得ない。それに加えて抵 抗係数に及ぼす流れの乱れの影響 14) むいまだ明らかで ない。また粒子径分布の広がりは球より大きい。そのよ うなととから粒子運動を表わす理論式は, 複雑で精巧な あのよりむしろ簡単なあののほうが使用に便利と考える。 そこで，粒子流量分布の重心を連ねる曲線を，数多くの 粒子の径路線の平均的なものと考え，その平均径路線は 代表粒子（粒子群の平均的な物理的性質をむった粒子） の径路線で示されるとして，それを求めることにする。

すなわち，水平な輸送管の上壁より，回転運動をと屯 なわずに一様な気流中に供給された代表粒子の運動は, あしその径があまり小さくなければ次の式てより表わす ことができるとする。

$$
\begin{aligned}
& m_{p} \ddot{x}=\frac{\gamma_{a} S}{2 g}\left\{(u-\dot{x})^{2}+\dot{y}^{2}\right\}^{2 / 1}(u-\dot{x}) C_{d} \\
& m_{p} \ddot{y}=m_{p} g-\frac{\gamma_{a} S}{2 g}\left\{(u-\dot{x})^{2}+\dot{y}^{2}\right\}^{1 / 2} \dot{y} C_{d}
\end{aligned}
$$

ただし, $m_{p}=\pi d_{p}{ }^{3} \gamma_{p} /(6 g), d_{p}$ : 粒子径, $x:$ 水平方向座 標, $\dot{x}: d x / d t, \ddot{x}: d^{2} x / d t^{2}, u$ : 輸送気流の速度, $y:$ 鉛直 方向座標, $\dot{y}: d y / d t, \ddot{y}: d^{2} y / d t^{2}, t$ : 時間, $C_{d}$ : 抵抗係数, $g$ : 重力の加速度, $\gamma_{p}, \gamma_{a}$ : 粒子の比重量および空気の比 重量である。

この式には粒子の比重が比重量の形ではいつているの

で，比重分級には役立つものと考えられる。

式中の $C_{d}$ は, 球に対しては粒子レイノルズ数 $R_{e p}$ の 相当大きな範囲 $R_{e p}=2 \sim 500$ まで

$$
C_{d}=\frac{k}{\sqrt{R_{e p}}}, \quad R_{e p}=\left\{(u-\dot{x})^{2}+\dot{y}^{2}\right\}{ }^{1 / 2}{ }^{d_{p}}
$$

なる形で表わされている。乙とに $\nu_{a}$ は空気の動粘性係 数である。 $C_{d}$ の值は $R_{e p}>1000$ では一定となる。 $R_{e p}$ $=500$ 1000 の間は簡単な式で近似するととは困難とさ れているが，乙こでは $R_{e p}$ 数の変化が大きくないので, $k$ の值を適当に選んで $R_{e p}=500 \sim 1000$ の間も式 (3) が 適用できるむのと仮定する。
式 (1)，(2) は $(u-\dot{x}) \gg \dot{y}$ が成立すれば簡単に解が求 まる。こてでは気流中に供給された粒子が管底に達する までの極く短い時間中の変化を取り扱うので，輸送気流 と粒子の速度差は, 粒子の落下速度より遙汃大きく, 上の条件は充分満足される。いま初期条件として粒子供 給孔出口の粒子の速度 (初速度) の水平成分が $x=0$ で 鉛直成分が $\dot{y}=\dot{y}_{0}$ である場合に，式 (1)，（2）の解を求 めることにする。

また

$$
\dot{x} / u=\phi, \quad \dot{y} / u_{g}=\theta, \quad g t / u_{g}=T
$$

で式 (1), (2) を無次元化し, 無次元水平速度 $\phi$, 無次元 水平変位 $\Phi$, 無次元鉛直速度 $\theta$, 無次元鉛直变位 $\Theta$ 屯同 時に求めることにする。

まず水平および鉛直方向の速度を求めれば

$$
\begin{aligned}
\dot{x}= & u-\left\{\frac{2}{\beta t+2 / \sqrt{u}}\right\}^{2} \\
\phi= & 1-\left\{\frac{2}{K T+2}\right\}^{2} \\
\dot{y}= & \frac{1}{3(2+\beta t \sqrt{u})^{2}} \\
& \times\left\{12 j_{0}+12 g t+6 g \beta \sqrt{u} t^{2}+g \beta^{2} u t^{3}\right\} \\
\theta= & \frac{12 \theta_{0}+12 T+6 K T^{2}+K^{2} T^{3}}{3(\overline{K T}+2)^{2}}
\end{aligned}
$$

となる。また水平および鉛直変位は

$$
\begin{aligned}
& x=u t\left(1-\frac{2}{2+\beta t \sqrt{u}}\right) \\
& \Phi=T\left(1-\frac{2}{K T+2}\right) \\
& y=\frac{1}{6(2+\beta t \sqrt{u})}\left(12 \dot{y}_{0} t+6 g t^{2}+g \beta \sqrt{u} t^{3}\right) \\
& \Theta=\frac{1}{K T+2}\left(2 \theta_{0} T+T^{2}+\frac{1}{6} K T^{3}\right)
\end{aligned}
$$

となる。

$$
\text { また式 (7), (7) より }
$$

$$
\begin{aligned}
& t=\frac{x}{2 u}\left(1+\sqrt{1+\frac{8 \sqrt{u}}{\beta x}}\right) \\
& T=\frac{\Phi}{2}(1+\sqrt{1+\stackrel{8}{K \Phi}})
\end{aligned}
$$

なる関係があるので，乙れを式 (8), (8) 亿代入すれば

$$
\begin{aligned}
y= & 6\left\{2+\frac{\beta x}{2 \sqrt{u}}\left(1+\sqrt{\left.\left.1+\frac{8 \sqrt{u}}{\beta x}\right)\right\}}\right.\right. \\
& \times\left\{\frac{6 \dot{y}_{0} x}{u}\left(1+\sqrt{1+\frac{8 \sqrt{u}}{\beta x}}\right)+\frac{3 g x^{2}}{2 u^{2}}\right. \\
& \times\left(1+\sqrt{1+\frac{8 \sqrt{u}}{\beta x}}\right)^{2}+\frac{g \beta x^{3}}{8 u^{5 / 2}} \\
& \left.\times\left(1+\sqrt{1+\frac{8 \sqrt{u}}{\beta x}}\right)^{3}\right\}
\end{aligned}
$$




$$
\begin{aligned}
= & 6\left(2+\frac{\beta}{\sqrt{u}} \chi\right) \\
& \times\left(\frac{12 \dot{y}_{0}}{u} \chi+\frac{6 g}{u^{2}} \chi^{2}+\frac{g \beta}{u^{5 / 2} \chi^{3}}\right) \\
\Theta= & 2+\frac{K \Phi}{2}\left(1+\sqrt{1+\frac{8}{K \Phi}}\right) \\
& \times\left\{\theta_{0} \Phi\left(1+\sqrt{1+\frac{8}{K \Phi}}\right)\right. \\
& +\frac{\Phi^{2}}{4}\left(1+\sqrt{1+\frac{8}{K \Phi}}\right)^{2} \\
& \left.+\frac{K \Phi^{3}}{48}\left(1+\sqrt{1+\frac{8}{K \Phi}}\right)^{3}\right\} \\
= & \frac{1}{}{ }^{4}+4\left(2 \theta_{0} \Psi+\frac{1}{2} \Psi^{2}+\frac{K}{24} \Psi^{3}\right)
\end{aligned}
$$

をうる。

ただし

$$
\begin{aligned}
& \chi=\frac{x}{2}\left(1+\sqrt{1+\frac{8 \sqrt{u}}{\beta x}}\right) \\
& \Psi=\frac{\Phi}{2}\left(1+\sqrt{1+\frac{8}{K \Phi}}\right) \\
& K=\frac{3}{4} k \frac{\gamma_{a}}{\gamma_{p}} \frac{\nu^{1 / 2}}{g} \frac{u^{1 / 2} u_{g}}{d p^{3 / 2}}=\beta \frac{u^{1 / 2} u_{g}}{g} \\
& \beta=\frac{3}{4} k \frac{\gamma_{a}}{\gamma_{p}} \frac{\nu_{a}{ }^{1 / 2}}{d^{3 / 2}} \\
& \theta_{0} \text { ：無次元初速度の水平方向成分 }
\end{aligned}
$$

である。

また $C_{\boldsymbol{d}}=$ 定数で式 (1)，（2）を解けば

$$
\begin{aligned}
\dot{x}= & -\frac{A^{2} u^{2} t}{1+A^{2} u t} \\
\phi= & M T \\
\dot{y}= & \frac{2 \dot{y}_{0}+2 g t+A^{2} g u t^{2}}{2\left(1+A^{2} u t\right)} \\
\theta= & \frac{2 \theta_{0}+2 T+M T^{2}}{2(M T+\overline{1})} \\
x= & u t-\frac{1}{\dot{A}^{2}} \ln \left|1+A^{2} u t\right| \\
\Phi= & T-\dot{1}^{1} \ln |M T+1| \\
y= & 4 \ddot{A}^{4} \dot{u}^{2}\left[2\left\{2 \dot{y}_{0} a^{2} u-g\right\} \ln \left|1+A^{2} u t\right|\right. \\
& \left.+g\left\{\left(1+A^{2} u t\right)^{2}-1\right\}\right] \\
\Theta= & \frac{T}{2 \bar{M}}+\frac{T^{2}}{4}+\frac{\theta_{0} M-0.5}{M^{2}} \ln |M T+1|
\end{aligned}
$$

をうる。

ただし，

$$
\begin{aligned}
& A^{2}=\begin{array}{lll}
3 & \gamma_{a} & C_{d} \\
4 & \gamma_{p} & d_{p}
\end{array} \\
& M=A^{2} \frac{u u_{g}}{g}
\end{aligned}
$$

である。

てれまでの終速度はつぎの算式を用いている。

$$
\begin{aligned}
& u_{g}=\left(\frac{4}{3} \cdot \frac{\gamma_{p}}{\gamma_{a}} \frac{g d p}{C_{d}}\right), \quad C_{d}=\text { 定数 } \\
& u_{g}=\left\{\frac{16}{9}\left(\frac{\gamma_{p}}{\gamma_{a}}\right)^{2} \frac{g^{2}}{k^{2} \nu_{a}}\right\}^{1 / 3} d_{p}, \\
& C_{d}=\frac{k}{\sqrt{R_{e p}}}
\end{aligned}
$$

以上により，計算で粒子の流量分布の重心を求めるには, 式 (10), (10)' か (16), (16)' (17), (17)' かのいずれかお よび式 (20) か (21) を用いればよい。

なお測定結果を無次元化するには

$$
\Phi=\int_{0}^{T} \phi d T=\frac{g}{u_{g} u} \int_{0}^{t} \dot{x} d t, \quad \int_{0}^{t} \dot{x} d t=x
$$

であるので

$$
\Phi=\frac{g}{u u_{g}} x
$$

また

$$
\Theta=\int_{0}^{T} \theta d T=\frac{g}{u_{g^{2}}^{2}} \int_{0}^{t} \dot{y} d t, \quad \int_{0}^{t} \dot{y} d t=y
$$

であるので

$$
\Theta=\frac{g}{u_{g}^{2}} y
$$

となる。それで，式 (22), (23) を使えばよい。

式 (3) 中の $k$ の值は球に対するあのをとり

$$
\begin{array}{ll}
k=10, & R_{e p}=2 \sim 500 \\
k=13, & R_{e p}=500 \sim 700
\end{array}
$$

を用い, $R_{e p}>1000$ に対する $C_{d}$ の值としては, 実験範 囲が $R_{e p}=1000 \sim 2000$ では

$$
C_{d}=0.43
$$

を用いればよいととにする。

\section{3. 装駼装置および寒駼方法}

\section{1 実験装置}

第 1 図に実験装置の概要を示す。Aは風洞，B は整流 格子である。Bで整流された輸送気流は Aの末端で絞ら れ, 輸送管 $\mathrm{C}$ を通り $\mathrm{D}$ 上にとりつけられた粒子供給筒 $\mathrm{R}$

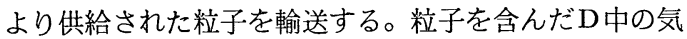
流は分岐管 $\mathrm{H}$ を通りサイクロン J で粒子のみを分離す る。気流はその後排出管 $\mathrm{K}$ 経て上部タンク $\mathrm{N}$ 亿集めら れ，送風機 $\mathrm{Q}$ により外部へ排出される。この際の流量は 丸ノズル $\mathrm{P}$ で計量される。粒子の供給は筒 $\mathrm{R}$ 内の輸送管 上板に明けられた約 $2 \times 5 \mathrm{~mm}^{2}$ の溝加らテコ式送り操 作と重力沈降法により行なう。測定断面を通過する粒子 の流量分布は，第 1 図の下に示すように，管路Dを重力 

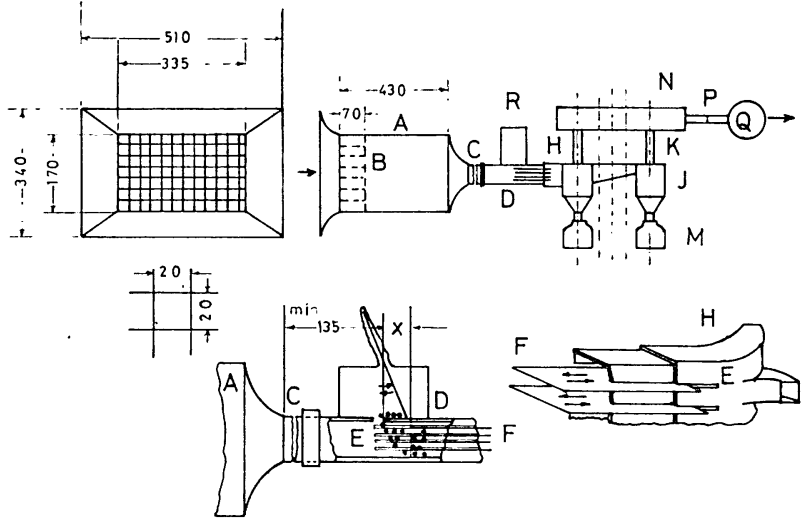

第1図実 験 装 置

方向に 5 等分した仕切板で混合気を 5 層に分け, 各層内 に含まれる粒子をサイクロンで分離し，捕集瓶 $\mathrm{M}$ 亿集め られたものを科量して求められる。したがって，4 枚の 仕切板前縁で形成する断面が測定断面となる。仕切板は 溝 $\mathrm{E}$ 亿はめ込まれているので, 前後に移動可能である。 てれを調節して供給孔より測定断面までの距離 $x$ を自 由に変える。距離 $x$ を大きく変えるには，輸送管 $\mathrm{C} の$ 上板に $100 \mathrm{~mm}$ 括きに明けられた粒子供給孔上に筒 $\mathrm{R}$ を移し書えて粒子供給を行なう。使用しない供給孔には 盲盍をしている。粒子供給孔より管内一出入する気流は 望ましくないので, 筒 $\mathrm{R} は$ 気密にして使用している。溝 $\mathrm{E}$ 屯外部より気流が侵入しないように気密にされてい る。なお第 1 図はおすに装置の機能を示していて，各部 の寸法比は正しくない。

\section{2 使用粒子}

使用粒子はガラスビーズ $570 \mu$ である。細かくふる

第1表 粒子径および比重量

\begin{tabular}{|c|c|c|c|c|c|}
\hline \multirow{2}{*}{\multicolumn{3}{|c|}{ 粒子の種類 }} & \multirow{2}{*}{\multicolumn{2}{|c|}{ 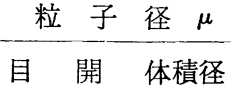 }} & \multirow{2}{*}{$\begin{array}{c}\text { 比重 量 } \\
\times 10^{3} \mathrm{~kg} / \mathrm{m}^{3}\end{array}$} \\
\hline & & & & & \\
\hline ガ & ラ & z & $\begin{array}{l}500 \\
590\end{array}$ & 572 & 2.51 \\
\hline ガ & ラ & z & $\begin{array}{l}1000 \\
1190\end{array}$ & 1158 & 2.51 \\
\hline \multicolumn{3}{|c|}{ フライアッシュ } & ${ }_{125}^{105}$ & 115 & 2.12 \\
\hline 砂 & & 鉄 & ${ }_{125}^{105}$ & 133 & 4.97 \\
\hline 砂 & & 鉄 & $\begin{array}{l}210 \\
250\end{array}$ & 250 & 4.55 \\
\hline 標 & 準 & 砂 & $\begin{array}{l}210 \\
250\end{array}$ & 245 & 2.65 \\
\hline 砥 & & 粒 & $\begin{array}{l}105 \\
125\end{array}$ & 120 & 3.97 \\
\hline
\end{tabular}

い分けられたむの多数を秤量してその重量を 求め, さらにその個数を求めて一個当りの平 均重量を出し, それより球相当体積径を出し て平均径（代表径）としている。その值は第 1 表に示している。第 1 表には続報に使用す る粒子のあのも示している。使用粒子の粒度 分布をグリーン径と個数により第 2 図に示 す。ガラスビーズ $570 \mu$ は粒子径が 200 $1000 \mu$ の間のあのでは, あっとあ球形度がよ く，また粒子分布も狭い範囲任集中している。 粒子の比重量は，高周波発生装置を用いて 粒子表面に付着している気泡を除き，ピクノ メータにより測定した。測定值を第 1 表に示 す。

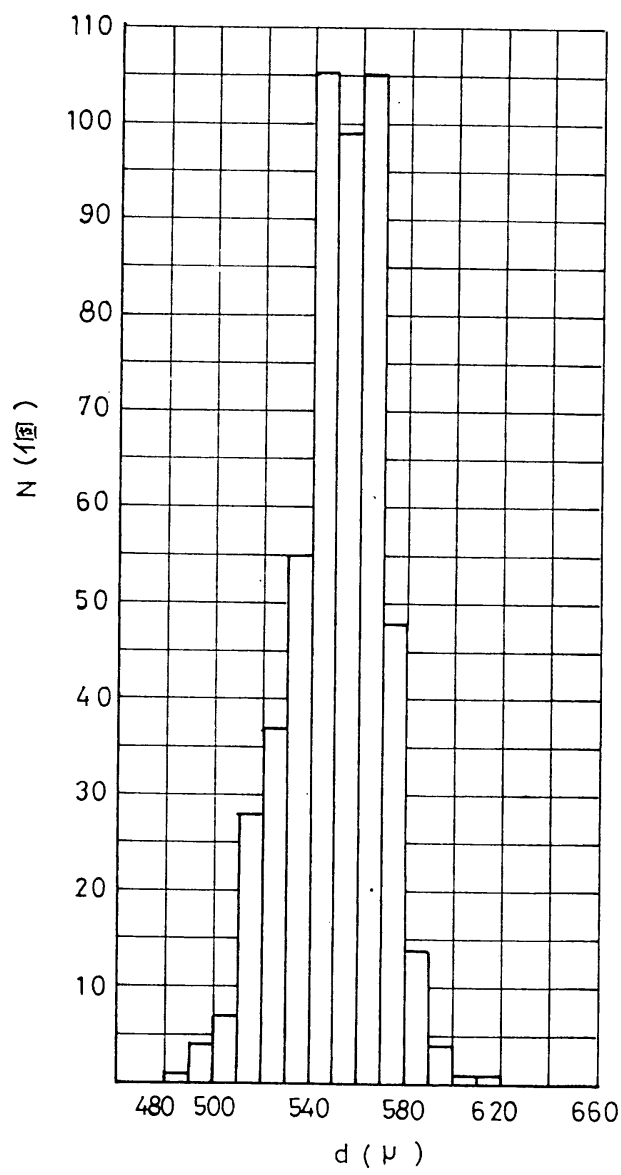

第 2 図粒子の粒度分布

\section{3 粒子の初速度 $\dot{y}_{0}$}

粒子が輸送気流中にはいり込む際の初速度 $\dot{y}_{0}$ は，実 測が容易でないので，計算により求めた。計算誤差を小 さくするために，供給筒 Rを気密にしているので，Rよ 
第2表初速度および終速度

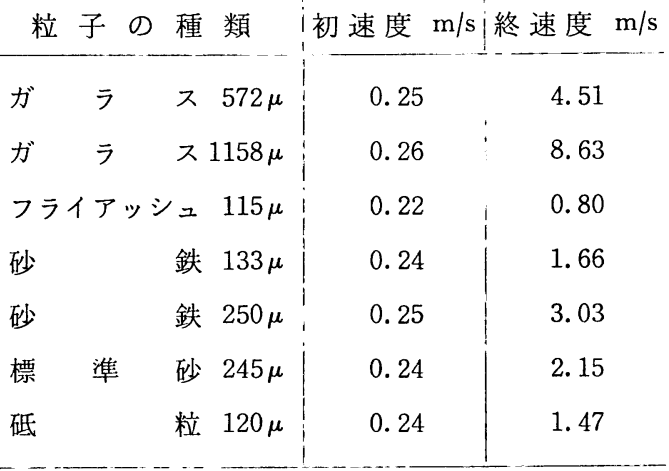

りDへの落下を静止気流中の自由落下として取り扱つか った。すなわち

$$
\dot{y}_{0}=u_{g}\left(1-e^{-\frac{g}{u_{g}} t}\right)
$$

$t$ を求めるには

$$
y=u_{g} t-\frac{u_{g}^{2}}{g}-\left(1-e^{-\frac{g}{u_{g}^{-}} t}\right)
$$

なる式を用いた。 $y$ は上壁板の厚さ $3 \mathrm{~mm}$ と粒子半径 $d_{p} / 2$ との和である。 $t$ は $y$ なる距離を粒子が落下する に要する時間である。 $u_{g}$ は粒子の終速度で，乙の際は 粓子速度が小さいので，粒子抵抗をストークス則に従う として

$$
\begin{aligned}
& u_{g}=\gamma_{p} d_{p}^{2} /(18 \mu) \\
& \mu: \quad \text { 気流の粘性係数 }
\end{aligned}
$$

により求めた。各計算値は第 2 表に示す。

\section{4 粒子の流五分布重心}

簡単で合理的な仮定として，粒子の径と，あるいは 粒子の運動と分布の両方に役立つように規定されるか あしれない形状の分布をとあに正規分布とする。流体 の流れは整流されているが，変動やゆらぎ成分は全く ランダムなあのである。そのようなランダムな成分を むつた流れのなかに，正規分布をなす物理的性質をむ った粒子を供給すれば，流れのなかの粒子は正規分布 に近い流量分布をなして流動するすのと考えうる。そ のため粒子流量分布の重心は，正規確率紙を用い，測 定断面での粒子の重量分布より求めた重量集積割合を縦 軸に，上壁板よりの距り $y$ を横軸にとり，重量集皘割 合 $50 \%$ 前後の测定点を直線で結び，その $50 \%$ 相当の $y$ 座標を重心の $y$ 座標とした。重心の $x$ 座標は測定断 面の $x$ 座標である。

\section{4. 突験結累および考察}

整流された流れのなかに供給筒 $\mathrm{R}$ 内のガラスビーズ

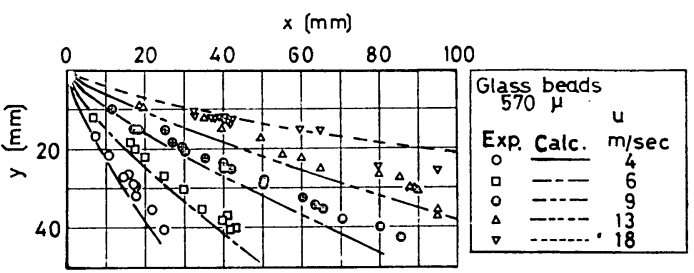

第3 図 気流中の粒子の流量分布重心

$570 \mu$ を供給し，供給孔より測定断面までの距離を変え て得られた粒子流量分布重心の実験結果之, 式 (10) に より求められた理論曲線とを第 3 図に示す。輸送気流の 平均速度は $4,6,9,13,18 \mathrm{~m} / \mathrm{s}$ の 5 種類である。図で は理論曲線と実験点とはかなりよく一致しているが，球 形度のよい粒子の実験結果としては充分とはいいがた い。したがって，その理由について考察する。粒子の供 給は前述のように気密室からの自然落下であるので，初 速度の算出結果は充分正確なあのと考えられる。粒子が 遭遇する気流の速度分布 ${ }^{16)}$ は, 粒子供給孔が本実験で は流れの絞り部下流 $135 \mathrm{~mm}$ の所であったので，充分 フラットであり平均速度を用いた取り扱いに無理がある とは考えられない。このように考えると, 理論曲線の算 出誤差に最も影響を与えるものは粒子の抵抗係数の選び 方にあるように思われる。球の抵抗係数は定数で示され る領域ああるが，粒子レイノルズ数の関係として示され る領域が広い。粒子レイノルズ数の関数として粒子の抵 抗係数を示した式 ${ }^{17 \sim 19)}$ はすでに多数発表されていて， なかであ田中の式 ${ }^{19)}$ は正確である。とてであ田中の式 を用いることが考えられるが，同式は複雑であり電算器 の使用を必要とする。一方ととに示す方法の適用が望ま れるのは球よりむしろ不規則形状粒子である。しかしな がら不規則形状粒子の抵抗係数は球ほど明確にされてお .らず，粒子レイノルズ数の関係で表わされる見通しあ明 らかでない。そのため，乙こでは精密度より理論的取り 扱いの可能性を確かめることをおむな目的として，理論 式の解が得られる形式の抵抗則を用い，その抵抗則の性 質と計算誤差との関係をしらべ，理論式の合理性を検 討した。

まず輸送気流の平均速度 $4 \mathrm{~m} / \mathrm{s}$ の場合を考える。乙 の際の粒子レイノルズ数は 160 である。すなわち粒子 が気流にはいり込んだ瞬間の粒子と輸送気流の相対速度 は気流速度に著しく，それにより求めたレイノルズ数が 160 で，時間ととあに相対速度が小さくなるので，粒子 レイノルズ数む小さくなる。このレイノルズ数範囲に相 当する抵抗係数を Lapple ${ }^{20)}$ の測定值より求め, 式 (3) の $k$ の值を逆算すれば，約 11 となる。計算では $k=10$ を用いているので，抵抗係数を小さく見積ったてとにな る。そのため計算により求めた曲線が実験点より下にあ 
$\Phi$

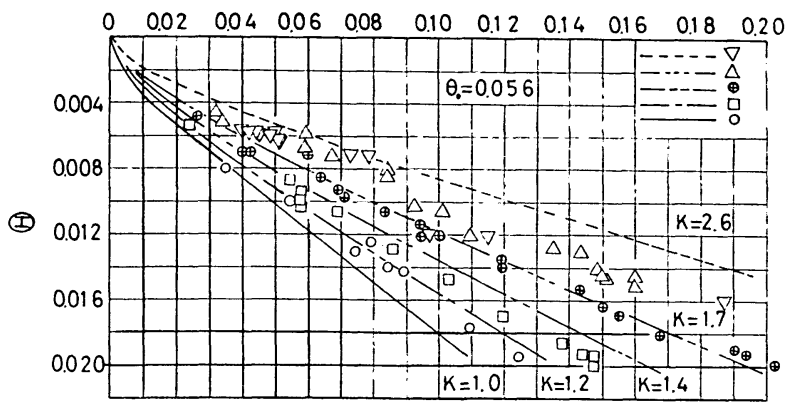

第 4 図 気流中の粒子の無次元分布重心
5. 結語

単粒子の運動方程式の解として得られた粒子流 量分布重心は，もし抵抗係数が適当であれば充分 な精度をむつ。したがって，ての方法を用いれば 気流による比重分級の研究が容易になるととが考 えられる。

また，実験結果より抵抗係数 $C_{d}$ を求めれば, それは粒子群の平均抵抗係数を示すととになる。 それでこの方法は不規則形状粒子の平均抵抗係数 測定に役立つあのと考えられる。

\section{参考 文 献}

るのは合理的である。平均風速 $6,9,13 \mathrm{~m} / \mathrm{s}$ の場合も 同様なととがいえる。平均風速 $18 \mathrm{~m} / \mathrm{s}$ の場合は少し異 る。粒子レイノルズ数は 660 である。こてで用いた $k$ の值は 13 である。この值は粒子が気流中にはいり込ん だ瞬間にのみ正しく，そのあとは大きすぎる值である。 したがって計算により求めた曲線が実験点より上にある のは合理的である。以上により全理論曲線之実験点の関 係はすべて合理的で，抵抗係数が正しければ，理論曲線 と実験点之は充分な精度で一致するととが考えられる。 このことは実験結果より $C_{a}$ を求めれば，それは使用粒 子の平均係数を表わすととを意味する。

つぎに第 3 図を無次元化したものを第 4 図に示す。図 のなかの曲線は式 (10)' で求められ, 実験点は式 (22), (23) で求められている。第 4 図の $k=1.0,1.2,1.4,1.7$ が第 3 図の $u=4,6,9,13,18 \mathrm{~m} / \mathrm{s}$ 亿対応している。理 論曲線之実験点のズレは，傾向は第 3 図に一致し，量は 㹡大されている。それは座標軸のスケールのとり方に よる。また，第 3 図ではパラメータが見掛け上は一つ

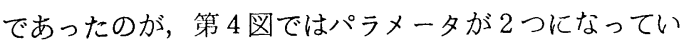
る。このうち $\theta_{0}$ は無次元初速度を表わしているが，空 気輸送ではての值が定数（ 0 か 1 ) にならない。水力輸 送では $\theta_{0}=1$ は容䀛に実現できるので, 無次元表示は気 流分級より水力分級に対してより効果的と考えられる。 しかしながら，無次元的取り扱いが可能であるととは， 粒子や転送流体の種類にかかわらずに利用できて便利で ある。
1）野満他：地球物理学，6，16（1942）

2) 速水: 地球科学, 2,5 (1950)

3）簿原他：九大応力研究所報告, 10,63 (1957)

4) L. Prandtle: Fluid Dynamic, 336, Blackie (1952)

5）新津他：機械学会論文集，26-162，170（1960）

6) R. Briller and M. Robinson: Aiche. J., 15-5, 734 (1959)

7）池森：エ八ラ時報，4-2，2（1955）

8) S. L. Soo, etal: J. B. E. Sep., 609 (1960)

9）植松，森川：機械学会論文集, 26-171, 1522 (1960)

10）井伊谷, 後藤：化学工学, 26-1，75 (1964)

11) G. Welschof: VDI-Fo4 ${ }_{4} \mathrm{rch}, 492,17$ (1962)

12）鶴見：土木学会誌，18-10，1（1932）

13）菅原他：機械学会論文集，23-125，63（1957）

14) L. B. Torobin, etal: Canad. J. Chem. Eng. Dec., 193 (1960)

15) Auerbach-Hort Handbuch Der Physichalischen und Technischen Mechanik, 6, 783

16）坂本：熊本大学教育学部紀要，23-1，5 (1974)

17) S. Goldstein: Proc. Roy. Soc., London (A), 123 225 (1929)

18) L. Schiller and A. Nauman: Z. V. D. I., 77, 315 (1933)

19) Z. Tanaka: J. Chem. Eng. Japan, 3-2, 261 (1970)

20) C. E. Lapple and C. B. Schepherd: Ing. Eng. Chem., 23-5, 605 (1960) 